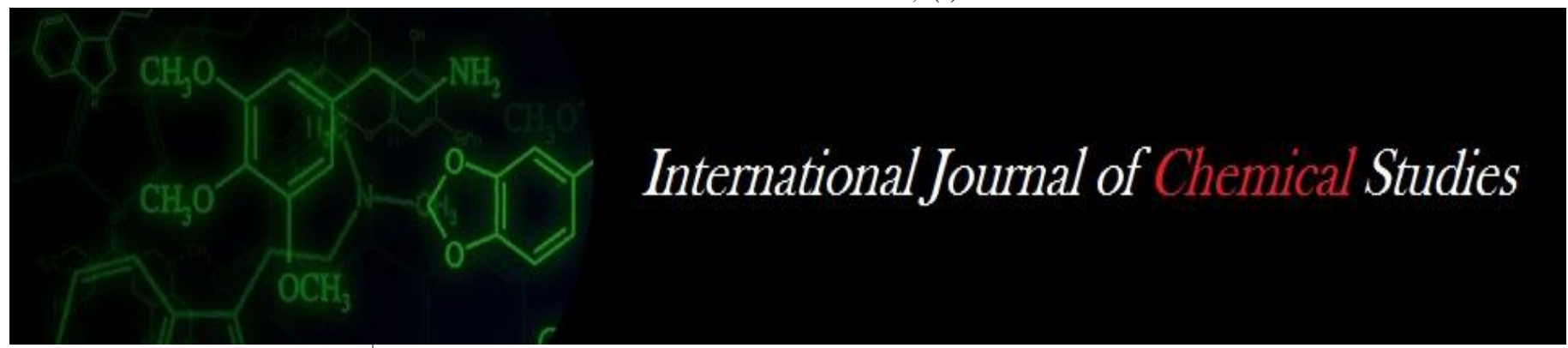

P-ISSN: 2349-8528

E-ISSN: 2321-4902

www.chemijournal.com

IJCS 2020; 8(2): 2951-2954

(C) 2020 IJCS

Received: 15-01-2020

Accepted: 19-02-2020

\section{PD Paralkar}

M.Sc. Student, Vasantrao Naik Marathwada Krishi Vidyapeeth, Parbhani, Maharashtra, India

\section{SG Patil}

Officer Incharge, Sweet Orange Research Station, Badnapur,

Maharashtra, India

UM Naglot

Assistant, Professor, COA

Badnapur, Maharashtra, India
Corresponding Author:

PD Paralkar

M.Sc. Student, Vasantrao Naik

Marathwada Krishi Vidyapeeth,

Parbhani, Maharashtra, India

\section{Effect of chemicals on fruit retention of mango (Mangifera indica L.) Cv. Kesar}

\author{
PD Paralkar, SG Patil and UM Naglot
}

DOI: https://doi.org/10.22271/chemi.2020.v8.i2as.9199

\section{Abstract}

The present investigation entitled "Effect of chemicals on fruit retention and quality of mango (Mangifera indica L.) Cv. Kesar" was conducted at Fruit Research Station, Himayatbagh, Aurangabad during the year 2016-17. The objective of this experiment was to improve the fruit retention of mango $\mathrm{Cv}$. Kesar by using NAA, $\mathrm{KNO}_{3}$, Urea and Triacontanol. The experiment was laid out in Randomized Block Design (RBD) with three replication and 13 treatments. Comprising spraying of NAA (@ each 20, 40,60 ppm), $\mathrm{KNO}_{3}$ (@ each 2, 4,6\%), Urea (@ each 1, 1.5,2\%), Triacontanol (@ each 100,300,500 ppm) and control. The observations on different characters of fruit Viz, per cent fruit set per panicle, per cent fruit retention pea and marble stage, weight of fruit $(\mathrm{g})$, volume of fruit (ml), Mesocarp-pulp (g), Exocarp- skin (g), Endocarp-stone (g), Number of fruit per tree, Yield per tree $(\mathrm{kg})$, Yield per ha $(\mathrm{t})$. Were recorded.

Among the treatments, $T_{13}$ Triacontanol $500 \mathrm{ppm}$ recorded maximum increase in fruit set per panicle, fruit retention pea stage, fruit retention at marble stage, weight of fruit $(\mathrm{g})$, volume of fruit $(\mathrm{ml})$, Mesocarp-pulp (g), Exocarp-skin (g), Endocarp-stone (g), Number of fruit per tree, Yield per tree (kg), Yield per ha (t).

Keywords: Fruit set, triacontanol, NAA, fruit retention

\section{Introduction}

Mango (Mangifera indica L.) is the king of fruits in India and got a unique position in Indian Horticulture. It is native to India (Indo Burma region). Botanically mango belong to family Anacardiaceae and cultivated mango belongs to Mangifera indica species and wild mango belongs to Mangifera sylvatica and Mangifera khaisana are said to be exist in India.

The mango fruit has been in cultivation in Indian continent for well over 4000 years and has been the favorite of the kings and commoners because of its nutritive value, taste, attractive fragrance and health promoting qualities and now it is recognized as one of the best fruits in the world market.

The total area under cultivation of mango in India is 2273 (000 ha) and production is around 19218 (000MT) according to NHB (2016-2017). In India states Andhra Pradesh, Karnataka, Gujarat, Maharashtra, Tamil Nadu, Chhattisgarh, Bihar and Uttar Pradesh are the leading in production of mango.

It has great adaptability and thrives in a wide range of climatic and soil conditions. It is grown throughout the length and breadth of the country under a wide range of agro climatic situations, except temperate regions. It has low cost of cultivation and maintenance. Mango can be grown on wide variety of soils under varied climatic conditions. The temperature between 24 and $27{ }^{\circ} \mathrm{C}$ is ideal for its cultivation. It can be grown best in region with a rainfall between 25 and $250 \mathrm{~cm}$. Regions having bright sunny days and moderate humidity during flowering are ideal for mango growing.

Kesar is a leading variety of Gujarat with a red blush on the shoulders. It is a superior chance seedling of Junagarh but resembles in nature with South-Indian mangoes. It has been observed that, a large area is under cultivation of this variety in Maharashtra particularly in Marathwada. This variety has export potential. However, the farmers are facing problems of low fruit set, fruit drop and poor quality in terms of size of fruit. In mango production, yield and quality is influenced by several factors including nutritional and environmental factors. Imbalanced fertilization is considered to be one of the major contributing factors for the low productivity. 
Marathwada region is famous for mango plantation mostly of seedling origin. It is extensively grown in almost all districts of Marathwada region particularly Aurangabad, Beed and Nanded district. The orchard of Himayatbagh is the collection of mango made by the Nizam Among these all varieties of mango, Kesar are high yield potential, almost regular bearer, mid-season variety, having good consumer acceptance, attractive shape, size, saffron colored pulp and very good keeping quality. In light of the views mentioned above, the present study "Effect of chemicals on fruit retention and quality of mango (Mangifera indica L.) Cv. Kesar" was taken up under the agro climatic conditions prevailing at Fruit Research Station, Aurangabad hence considering the need, the present investigation study to improve the fruit retention of mango $\mathrm{Cv}$. Kesar by using NAA, $\mathrm{KNO}_{3}$, Urea and Triacontanol.

\section{Materials and Methods}

The present investigation was conducted during 2016-2017 on grafted mango cultivars grown at mango orchard, Fruits Research Station Aurangabad. Aurangabad is situated at $19^{0}$ and $20^{\circ}$ North latitude and $74^{\circ}$ and $76^{\circ}$ East longitude and altitude 409 meter above mean sea level. The climate is generally dry for eight months of the year and wet during south-west monsoon season. The mean rainfall is approximately $662 \mathrm{~mm}$ and is received from June to September. Rainfall is not well distributed in all the parts of district and year. The maximum temperature in summer month goes up to $41.6{ }^{\circ} \mathrm{C}$. The cold weather commences from the middle of November when temperature starts falling and minimum temperature goes down up to $10{ }^{0} \mathrm{C}$. Thus Aurangabad is fairly cool in winter and sufficiently hot in summer, the mean relative humidity ranges from 12 to 90 per cent.

The orchard was established by procuring uniform mango graft of Kesar, Fruit Research Station, Aurangabad during 2008. The trees were planted at spacing 5 X $5 \mathrm{~m}$. These grafts were maintained with uniform horticultural practices. Out of above Cv. Kesar was selected to study "Effect of chemicals on fruit retention of mango (Mangifera indica L.)". Experiment was laid out in Randomized Block Design with three replications and thirteen treatments these are. $T_{1}$ control, $\mathrm{T}_{2} \quad \mathrm{NAA} @ 20 \mathrm{ppm}, \quad \mathrm{T}_{3} \mathrm{NAA} @ 40 \mathrm{ppm}, \quad$ T 4 NAA@ 60ppm., $\mathrm{T}_{5} \mathrm{KNO}_{3} @ 2 \%, \mathrm{~T}_{6} \mathrm{KNO}_{3} @ 4 \%, \mathrm{~T}_{7} \mathrm{KNO}_{3} @ 6 \%, \mathrm{~T}_{8} \mathrm{Urea}, @ 1 \%$, T9Urea@1.5\%, T10 Urea@2\%, T 11 Triacontanol@100ppm, T12 Triacontanol@300ppm, $\mathrm{T}_{13}$ Triacontanol@500ppm For recording the observations on the various parameters, four uniform bearing panicles on the North, South, East and West site of the tree were selected during peak period of flowering randomly on each tree and tagged with labels.

The chemicals as per the treatments, were applied as a foliar spray to panicles at full bloom stage (flowering), pea size stage and at marble size stage of fruits with the help of knapsack hand sprayer. The sprayer was thoroughly washed with distilled water after application of every chemical.
Randomly four panicles from all the sides were selected on each tree and average numbers of fruit set per panicle were recorded.

For recording the observation on fruit retention, the panicles from all four sides of the tree were selected and tagged. The observations of fruit retention per panicle were recorded at each stage. The stages were:1. Pea size stage 2. Marble size stage. Four fully mature fruits, one from each treated panicle were used for recording the observation and average was computed. Four fruits one from each treated panicle were selected. Weight of each fruit was noted on electronic balance. Average for each treatment in gram was computed. The volume of each fruit was estimated by water displacement method. The average was computed for each treatment and given in $\mathrm{ml}$. The pulp was extracted by hand, knife and weight was recorded presented as gram of total fruit weight. The skin was removed, made free from pulp and weight was taken and computed as gram of total fruit weight. The stone was cleaned so that no pulp remained adhering with the stone and the weight of stone was taken in gram. The number of fruits per tree were counted at each harvest after the completion of harvest the total number of fruits record. The fruit harvested from each plant, weight separately and total weight harvest record in $\mathrm{kg}$. For recording yield, total produce per ha was calculated as per fruit yield per ha in tones.

\section{Results and Discussion}

Among various treatments, Maximum fruit set per panicle $(97.75 \%)$ was recorded in treatment $\mathrm{T}_{13}$ Triacontanol 500 ppm, was statistically significant followed by treatment $\mathrm{T}_{3}$ NAA 40 ppm (87.41\%), T 4 NAA 60 ppm (85.57\%). $\mathrm{T}_{5} \mathrm{KNO}_{3}$ $2 \%(78.66 \%), \mathrm{T}_{7} \mathrm{KNO}_{3} 6 \%(77.00 \%)$ and $\mathrm{T}_{10}$ Urea 2 (74.75\%). Whereas, minimum fruit set per panicle $(63.25 \%)$ was observed in treatment $\mathrm{T}_{1}$ (control). The experiment revealed that, the beneficial role of chemicals tested on increasing the fruit set in mango $\mathrm{Cv}$. Kesar. Treatment $\mathrm{T}_{13}$ Triacontanol at $500 \mathrm{ppm}$ was found to be the statistically superior treatment in increasing fruit set $(97.75 \%)$. This might be due to application of Triacontanol, attributed to more efficient utilization of food for reproductive growth, flowering and fruit setting, higher photosynthetic efficiency and enhanced source to sink relationship in plants, increased uptake of nutrients and water, reduced transpiration and respiration, enhanced translocation and accumulation of sugar and other metabolites. Similar results found by Momin et al. (2016) ${ }^{[3]}$ in mango.

The data on fruit retention at pea stage (\%) is influenced by different treatments have presented in Table 1 . The data indicated that, the chemicals showed significantly maximum pea stage fruit retention as compared to control. Maximum pea stage fruit retention $(39.05 \%)$ was noticed in treatment $\mathrm{T}_{13}$ Triacontanol $500 \mathrm{ppm}$, which was at par with treatment $\mathrm{T}_{3}$ NAA 40 ppm (38.52\%) T TAA $_{4}$ Nopm (36.91\%), Treatment $\mathrm{T}_{2}$ NAA $20 \mathrm{ppm}(34.58 \%)$ and $\mathrm{T}_{6} \mathrm{KNO}_{3} 4 \%$ (34.48\%) whereas, minimum fruit retention $(26.83 \%)$ was observed in treatment $\mathrm{T}_{1}$ (control). 
Table 1: Effect of spraying of chemicals on per cent fruit set per panicle, per cent fruit retention at pea stage and marble stage weight of fruit $(\mathrm{g})$, volume of fruit $(\mathrm{ml})$ and mesocarp-pulp $(\mathrm{g})$ of mango.

\begin{tabular}{|c|c|c|c|c|c|c|c|}
\hline $\begin{array}{l}\text { Sr. } \\
\text { No. }\end{array}$ & Treatment details & $\begin{array}{l}\text { Fruit set per } \\
\text { panicle }(\%)\end{array}$ & \begin{tabular}{|c|} 
Fruit retention \\
at pea stage $(\%)$
\end{tabular} & $\begin{array}{l}\text { Fruit retention at } \\
\text { marble stage }(\%)\end{array}$ & $\begin{array}{l}\text { Weight of } \\
\text { fruit }(g)\end{array}$ & \begin{tabular}{|l} 
Volume of \\
fruit (ml)
\end{tabular} & $\begin{array}{l}\text { Mesocarp- } \\
\text { pulp (g) }\end{array}$ \\
\hline $\mathrm{T}_{1}$ & Control & 63.25 & 26.83 & 8.66 & 177.02 & 171.02 & 107.89 \\
\hline $\mathrm{T}_{2}$ & NAA@20ppm & 68.00 & 34.58 & 12.75 & 241.52 & 237.59 & 154.98 \\
\hline $\mathrm{T}_{3}$ & NAA@40ppm & 87.41 & 38.52 & 13.41 & 265.48 & 260.71 & 174.96 \\
\hline $\mathrm{T}_{4}$ & NAA@60ppm & 85.57 & 36.91 & 13.00 & 241.70 & 246.48 & 158.99 \\
\hline $\mathrm{T}_{5}$ & $\mathrm{KNO}_{3} @ 2 \%$ & 78.66 & 33.75 & 10.58 & 231.74 & 233.37 & 146.06 \\
\hline $\mathrm{T}_{6}$ & $\mathrm{KNO}_{3} @ 4 \%$ & 67.33 & 34.48 & 11.08 & 238.37 & 234.11 & 151.53 \\
\hline $\mathrm{T}_{7}$ & $\mathrm{KNO}_{3} @ 6 \%$ & 77.00 & 34.00 & 10.25 & 225.37 & 230.88 & 147.77 \\
\hline $\mathrm{T}_{8}$ & Urea@1\% & 64.83 & 33.20 & 9.41 & 187.72 & 182.01 & 115.84 \\
\hline $\mathrm{T}_{9}$ & Urea@1.5\% & 68.25 & 33.45 & 9.07 & 194.63 & 190.00 & 121.27 \\
\hline $\mathrm{T}_{10}$ & Urea@2\% & 74.75 & 30.35 & 10.16 & 218.68 & 212.68 & 136.39 \\
\hline $\mathrm{T}_{11}$ & Triacontanol@100ppm & 63.83 & 33.00 & 9.00 & 186.84 & 180.87 & 114.94 \\
\hline $\mathrm{T}_{12}$ & Triacontanol@300ppm & 73.33 & 31.23 & 10.08 & 202.01 & 196.98 & 125.95 \\
\hline $\mathrm{T}_{13}$ & Triacontanol@500ppm & 97.75 & 39.05 & 13.66 & 289.68 & 284.25 & 192.23 \\
\hline \multicolumn{2}{|r|}{ S.E.m \pm} & 3.50 & 1.62 & 0.56 & 10.50 & 10.33 & 6.72 \\
\hline \multicolumn{2}{|r|}{ C.D. at $5 \%$} & 10.23 & 4.73 & 1.65 & 30.65 & 30.15 & 19.62 \\
\hline
\end{tabular}

The data indicated that, the chemicals showed significantly Maximum marble stage fruit retention as compared to control. Maximum marble stage fruit retention (13.66\%), was noticed in treatment $\mathrm{T}_{13}$ Triacontanol $500 \mathrm{ppm}$, which was at par with $\mathrm{T}_{3}$ NAA $40 \mathrm{ppm}(13.41 \%), \mathrm{T}_{4} \mathrm{NAA} 60 \mathrm{ppm}(13.00 \%)$ and $\mathrm{T}_{2}$ NAA $20 \mathrm{ppm}(12.75 \%)$. Whereas, minimum fruit retention marble stage $(8.66 \%)$ was observed in treatment $\mathrm{T}_{1}$ (control).

The data revealed that, the treatment $\mathrm{T}_{13}$-Triacontanol at 500 ppm retain statistically more fruit per panicle pea stage (39.05\%) and marble stage $(13.66 \%)$, respectively than control. This might be due to application of Triacontanol, attributed to more efficient utilization of food for reproductive growth, flowering and fruit setting, higher photosynthetic efficiency and enhanced source to sink relationship in plants, increased uptake of nutrients and water, reduced transpiration and respiration, enhanced translocation and accumulation of sugar and other metabolites. Similar results found by Konhar and singh (1988) ${ }^{[2]}$ in cashew and Bhamare et al. (2014) ${ }^{[1]}$ in mango.

The data on weight of fruit (g) was influenced by different treatments have presented in Table 1 . The data indicated that, the chemicals showed significantly maximum fruit weight noticed as compared to control. Maximum fruit weight (289.68 g) was noticed in treatment $\mathrm{T}_{13}$ Triacontanol $500 \mathrm{ppm}$ which was at par with $\mathrm{T}_{3}$ NAA 40 ppm (265.48 g). Lowest weight of fruit $(177.02 \mathrm{~g})$ was noticed in treatment $\mathrm{T}_{1}$ control. The data on volume of fruit $(\mathrm{ml})$ was influenced by different treatments have presented in Table 1 Perusal of data from table 1 revealed that significantly maximum volume of fruit $(284.25 \mathrm{ml})$ was noticed in treatment $\mathrm{T}_{13}$ Triacontanol 500 ppm, which was at par with $\mathrm{T}_{3}$ NAA $40 \mathrm{ppm}$ (260.71 ml). Minimum fruit volume was observed in treatment $T_{1}$ control (171.02 ml).

The data on mesocarp-pulp (g) was influenced by different treatments have presented in Table 1 Perusal of data from table 1 indicated that significantly maximum mesocarp- pulp (192.23 g) was noticed in $\mathrm{T}_{13}$ Triacontanol $500 \mathrm{ppm}$ which was at par with treatment $\mathrm{T}_{3}$ NAA $40 \mathrm{ppm}$ (174.96 g). However, minimum mesocarp- pulp (107.89 g) was observed in treatment $\mathrm{T}_{1}$ control.

fruit weight $(289.68 \mathrm{~g})$, fruit volume $(284.25 \mathrm{ml})$ and Mesocarp-pulp (192.23 g) was noted under the treatment T13 (Triacontanol at $500 \mathrm{ppm}$ ) as compared to other treatments. This might be due to spraying of Triacontanol, attributed to more efficient utilization of food for reproductive growth, higher photosynthetic efficiency and enhanced source to sink relationship in plants, increased uptake of nutrients and water. Similar results found by Shinde et al. (2008) ${ }^{[4]}$ in mango.

The data on number of fruit per tree was influenced by different treatments have presented in Table 2. Perusal of data from table 2 indicated that, significantly maximum number of fruit per tree (204.46) was noticed in $\mathrm{T}_{13}$ Triacontanol 500 ppm, which was at par with treatment $\mathrm{T}_{3}$ NAA $40 \mathrm{ppm}$ (196.88), $\mathrm{T}_{4}$ NAA $60 \mathrm{ppm}$ (192.52), $\mathrm{T}_{2}$ NAA $20 \mathrm{ppm}$ (186.40), and $\mathrm{T}_{6} \mathrm{KNO}_{3} 4 \%$ (183.41). Whereas, minimum number of fruits (146.31) was observed in treatment $T_{1}$ control.

As per the results from present investigation, statistically maximum number of fruit per tree (204.46) was noticed in treatment $\mathrm{T}_{13}$ Triacontanol $500 \mathrm{ppm}$. This might be due to application of Triacontanol, increased photosynthetic activity in leaves and translocation of more photo assimilates. The experiment revealed the beneficial role of chemicals tested on increasing the number of fruit in mango Cv. Kesar. Similar results found by Momin et al. (2016) ${ }^{[3]}$ in mango.

An appraisal of data indicated that, the statistically maximum yield per tree $(55.76 \mathrm{~kg})$ was noticed in treatment $\mathrm{T}_{13}$ Triacontanol $500 \mathrm{ppm}$. The experiment revealed the beneficial role of chemicals tested on increasing the yield per tree in mango $\mathrm{Cv}$. Kesar. However, the perusal of the literature available fails to throw light on these findings.

The data on yield per tree $(\mathrm{kg})$ was influenced by different treatments have presented in Table 2. Perusal of data from table 2 revealed that, the maximum yield per tree $(55.76 \mathrm{~kg})$ was noticed in treatment $\mathrm{T}_{13}$ Triacontanol $500 \mathrm{ppm}$, which was at par with treatment $\mathrm{T}_{3}$ NAA $40 \mathrm{ppm}(52.24 \mathrm{~kg})$. Whereas, minimum yield per tree $(25.89 \mathrm{~kg})$ was observed in treatment $\mathrm{T}_{1}$ (control).

The data on yield per ha (t) was influenced by different treatments have presented in Table 2..Perusal of data from table 2 revealed that, the maximum yield per ha $(22.30 \mathrm{t})$ was noticed in treatment $T_{13}$ Triacontanol $500 \mathrm{ppm}$, which was at par with treatment $\mathrm{T}_{3}$ NAA 40 ppm (20.89t). Whereas, minimum yield per ha $(10.35 \mathrm{t})$ was observed in treatment $\mathrm{T}_{1}$ (control). As per the results from present investigation, statistically maximum yield per ha $(22.30 \mathrm{t})$ was noticed in treatment $\mathrm{T}_{13}$ Triacontanol $500 \mathrm{ppm}$. The experiment revealed that, the beneficial role of chemicals tested on increasing the yield per ha in mango Cv. Kesar. However, the perusal of the literature available fails to throw light on these findings. 
Table 2: Effect of spraying of chemicals on number of fruit per tree, yield per tree $(\mathrm{kg})$ and yield per hector $(\mathrm{t})$ of mango

\begin{tabular}{|c|c|c|c|c|}
\hline Sr. No. & Treatment details & Number of fruit per tree & Yield / tree (kg) & Yield /ha. (t) \\
\hline $\mathrm{T}_{1}$ & Control & 146.31 & 25.89 & 10.35 \\
\hline $\mathrm{T}_{2}$ & NAA@20ppm & 186.40 & 45.01 & 18.00 \\
\hline $\mathrm{T}_{3}$ & NAA@40ppm & 196.88 & 52.24 & 20.89 \\
\hline $\mathrm{T}_{4}$ & NAA@60ppm & 192.52 & 49.41 & 19.76 \\
\hline $\mathrm{T}_{5}$ & $\mathrm{KNO}_{3} @ 2 \%$ & 179.38 & 41.56 & 16.62 \\
\hline $\mathrm{T}_{6}$ & $\mathrm{KNO}_{3} @ 4 \%$ & 183.41 & 43.71 & 17.48 \\
\hline $\mathrm{T}_{7}$ & $\mathrm{KNO}_{3} @ 6 \%$ & 157.29 & 35.44 & 14.17 \\
\hline $\mathrm{T}_{8}$ & Urea@1\% & 149.79 & 28.11 & 11.24 \\
\hline $\mathrm{T}_{9}$ & Urea@1.5\% & 155.86 & 30.31 & 12.12 \\
\hline $\mathrm{T}_{10}$ & Urea@2\% & 150.99 & 33.01 & 13.20 \\
\hline $\mathrm{T}_{11}$ & Triacontanol@100ppm & 148.09 & 27.66 & 11.06 \\
\hline $\mathrm{T}_{12}$ & Triacontanol@300ppm & 151.74 & 31.71 & 12.28 \\
\hline $\mathrm{T}_{13}$ & Triacontanol@500ppm & 204.46 & 55.76 & 22.30 \\
\hline \multicolumn{2}{|r|}{ S.E.m \pm} & 8.19 & 2.02 & 0.75 \\
\hline \multicolumn{2}{|r|}{ C.D. at $5 \%$} & 23.93 & 5.90 & 2.20 \\
\hline
\end{tabular}

\section{References}

1. Bhamare SP, Patel HC, Singh B. Effect of PGRs on reduction of fruit drop in mango Cv. Mallika. The Asian journal of horticulture. 2014; 9(2):510-511.

2. Konhar T, Singh A. Effect of growth regulators on flowering fruit set and fruit retention in cashew (A. occidental). Indian Cashew Journal. 1988; 18(4):17-19.

3. Momin SK, Gaikwad SS, Patel RJ, Amarcholi JJ, Sharma KM. Effect of foliar application of chemicals on fruiting parameters of mango $\mathrm{Cv}$. Kesar. Research Journal of Agriculture sciences, 2016; 7(1):143-144.

4. Shinde BN, Pawar BR, Pawar DB, Kalalbandi BM. Effect of chemicals and growth regulators on physical characters of parbhani-bhushan mango. Karnataka J Agric. Sci. 2008; 21(2):318-319. 